\title{
Ризик розвитку остеоартрозу у хворих на ожиріння: мета-аналіз джерел літератури
}

Удк 796:612.357-085

\author{
О. М. Клецкова, Л. Д. Кравчук, і. О. Жарова, \\ П. Є. Гусєв
}

Національний університет фізичного виховання і спорту України, Київ, Україна

\begin{abstract}
Резюме. За останні 30 років у всьому світі кількість хворих на ожиріння зросла більш ніж удвічі. До змін в опорно-руховому апараті, що спричинені ожирінням, слід віднести дегенеративні та запальні ураження, і найчастіше це - остеоартроз. Остеоартроз впливає на всі аспекти життя через біль і обмеження рухливості, тому проблема лікування таких пацієнтів залишається актуальною.

Методи. Аналіз літературних джерел відносно впливу ожиріння на розвиток остеоартрозу на основі змін рівня клінічних та інструментально-діагностичних аспектів.

Результати. Остеартроз $є$ не просто хворобою старіння суглобів, а скоріше він спричинений процесом метаболічних порушень, при якому різні ліпідні, метаболічні та гуморальні медіатори запалення сприяють ініціації і прогресуванню процесу захворювання. Пацієнти з ожирінням та остеоартрозом, які втрачають вагу, можуть спостерігати зменшення симптомів остеоартрозу. Автори зазначають, що втрата ваги у таких пацієнтів пов'язана зі зменшенням таких запальних чинників, як C-реактивний білок (CRP), фактор некрозу пухлини (TNF) і інтерлейкін-6 (IL-6), які були пов'язані з порушенням фізичної функції. Ключові слова: остеоартроз, ожиріння, кульшовий суглоб, колінний суглоб.
\end{abstract}

\section{Риск развития остеоартроза у больных ожирением: мета-анализ источников литературы \\ О. М. Клецкова, Л. Д. Кравчук, И. А. Жарова, П. Е. Гусев}

Национальный университет физического воспитания и спорта Украины, Киев, Украина

Резюме. За последние 30 лет во всем мире количество больных ожирением выросло более чем вдвое. К изменениям в опорно-двигательном аппарате, вызванным ожирением, следует отнести дегенеративные и воспалительные поражения, и чаще всего - это остеоартроз. Остеоартроз влияет на все аспекты жизни через боль и ограничение подвижности, поэтому проблема лечения таких пациентов остается актуальной.

Цель. Анализ литературных источников о влиянии ожирения на развитие остеоартроза на основе изменений уровня клинических и инструментально-диагностических аспектов. Результаты. Остеоартроз не просто болезнь старения суставов, а скорее он вызван процессом метаболических нарушений, при котором различные липидные, метаболические и гуморальные медиаторы воспаления способствуют инициации и прогрессированию процесса заболевания. Пациенты с ожирением и остеоартрозом, уменьшающие вес, могут наблюдать уменьшение симптомов остеоартроза. Авторы отмечают, что потеря веса у таких пациентов связана с уменьшением таких воспалительных факторов, как C-реактивный белок (CRP), фактор некроза опухоли (TNF) и интерлейкин-6 (IL-6), которые были связаны с нарушением физической функции.

Ключевые слова: остеоартроз, ожирение, тазобедренный сустав, коленный сустав.

The risk of osteoarthritis in obese patients: A meta-analysis of literature sources O. M. Kletskova, L. D. Kravchuk, i. O. Zharova, P. Ie. Husev

National University of Physical Education and Sport of Ukraine, Kyiv, Ukraine

Abstract. The number of obese patients worldwide has more than doubled over the last 30 years. Changes in the locomotorium caused by obesity include degenerative and inflammatory lesions, 
and most often it is osteoarthrosis. Osteoarthrosis affects all aspects of life through pain and mobility limitations, therefore the problem of treating such patients remains relevant. Methods. Analysis of literature sources regarding the influence of obesity on osteoarthrosis development based on changes in the level of clinical and instrumental and diagnostic aspects. Results. Ostearthrosis is not just a disease of aging joints; it is rather caused by a process of metabolic disorders, during which various lipid, metabolic and humoral inflammatory mediators contribute to the initiation and progression of the disease process. Patients with obesity and osteoarthrosis, who are losing weight, may experience a reduction in the symptoms of osteoarthrosis. The authors note that weight loss in such patients is associated with a decrease in inflammatory factors such as C-reactive protein (CRP), tumor necrosis factor (TNF), and interleukin-6 (IL-6), which have been associated with physical function disorder.

Keywords: osteoarthrosis, obesity, knee joint.

Постановка проблеми. Ожиріння є загальновизнаною епідемією. За оцінкою ВООЗ понад 1,4 млрд дорослих мають надлишкову масу тіла, і з них понад 200 млн чоловіків і 300 млн жінок страждають на ожиріння [1-3]. Ця тенденція викликає занепокоєння: за 30 років у всьому світі кількість хворих на ожиріння зросла більш ніж удвічі [3-5]. Ожиріння пов'язане 3 підвищеним ризиком безлічі хронічних захворювань. До змін в опорно-руховому апараті, що спричинені ожирінням слід віднести дегенеративні та запальні ураження, а найчастіше - остеоартроз (ОА) [2], який впливає на всі аспекти життя через біль і обмеження рухливості. Тому проблема лікування таких пацієнтів залишається актуальною.

Мета дослідження - аналіз літературних джерел щодо впливу ожиріння на розвиток ОА на основі змін рівня клінічних та інструментально-діагностичних аспектів.

Аналіз останніх досліджень та публікацій. Ожиріння $є$ найбільшим модифрікуючим фактором ризику ОА [4-6]. Coggon і співавт. [7] повідомили, що у пацієнтів 3 індексом маси тіла (IMT) $>30 \mathrm{Kг} \cdot \mathrm{M}^{-2}$ ймовірність розвитку ОА колінного суглоба в 6,8 раза вище, ніж у когорті пацієнтів з нормальною масою тіла. Метааналіз M. Blagojevic [8] показав, що співвідношення шансів для розвитку остеоартрозу становить 2,63 (2,28, $3,05)$ для пацієнтів з ожирінням порівняно з контрольною групою з нормальною масою тіла [8].

Вплив індексу маси тіла (IMT) на частоту розвитку остеоартрозу як колінного, так і кульшового суглобів оцінювався в двох останніх метааналізаx Jiang та співавт. (включаючи когортні та рандомізовані дослідження) [9]. Вони зазначають про прямий зв'язок між IMT і ризиком ОА як колінних, так і кульшових суглобів (як за клінічними, так і за рентгенологічними ознаками). У своїй публікації автори зазначають, що 5-разове збільшення індексу маси тіла було пов'язане 3 35 \%-м підвищенням ризику ОА колінного суглоба (англ. Relative Risk - співвідношення ризиків
(RR)): 1,35; 95 \% Cl (англ. Confidence Interval випадковий розподіл $(\mathrm{Cl})):$ 1,21-1,51) і $11 \%$-м підвищенням ризику розвитку ОА кульшового суглоба ((RR): 1,11; 95 \% Cl: 1,07-1,16). Цікаво, що зв'язок між IMT та ОА колінного суглоба значно сильніший у жінок, ніж у чоловіків (чоловіки, RR: 1,22; 95 \% Cl: 1,19-1,25; жінки, RR: 1,38; $95 \%$ Cl: 1,23-1,54); тоді як при порівнянні остеоартрозу кульшового суглоба відносно статі такого сильного зв'язку не спостерігалось [9].

Ожиріння в ранньому віці може бути особливо небезпечним. Так, Holliday та співавт. [11] виявили, що у пацієнтів, які страждають на ожиріння з дитинства чи юнацтва, більш високий ризик розвитку ОА нижніх кінцівок ( $p<0,001$ для ОА колінного суглоба і ОА кульшового суглоба).

Цікавим $€$ популяційне дослідження Reijman та співавт. [12], яке було проведено у двох напрямках :

- дослідження взаємозв'язку між IMT і захворюваністю на ОА;

- спостереження протягом 6,6 років динаміки прогресування за рентгенологічними ознаками остеоартрозу колінного і кульшового суглобів у пацієнтів з ожирінням та надлишковою масою тіла.

У пацієнтів $з$ надмірною масою тіла (IMT > $25 \mathrm{\kappa г} \cdot \mathrm{M}^{-2}$ ) спостерігався підвищений ризик виявлення інцидентів OA колінного суглоба (RR 3,3; $95 \% \mathrm{Cl}: 2,1-5,3)$, але не ОА кульшового суглоба (RR: 1,0; 95 \% Cl: 0,7-1,5). Високий IMT $\left(>27,5 \mathrm{kг} \cdot \mathrm{M}^{-2}\right)$ також був пов'язаний з прогресуванням OA колінного суглоба (RR 3,2; $95 \%$ Cl: 1,1-9,7), який оцінювався за рентгенологічними ознаками, а саме - за зменшенням ширини суглобового простору на рентгенограмі. Але такі показники IMT не були значущим для OA кульшового суглоба ((RR): 1,5; $95 \%$ Cl: 0,6-3,7)). Як зазначають автори, кореляція за клінічними даними $\epsilon$ також важливою, враховуючи відому невідповідність між тяжкістю структурного пошкодження і тяжкістю симптомів [12, 
13]. Існуючі визначення ОА, ймовірно, будуть переглянуті, оскільки МРТ все більше застосовується для діагностики ОА. Те, що в даний час ідентифікується як рання рентгенологічна зміна, може фрактично являти собою більш пізню стадію захворювання.

Оскільки артроскопічні втручання значно поширені в практиці лікування патологій суглобів, то було б цікавим дослідити та відповісти на питання: чи існує зв'язок між IMT та необхідністю проведення артропластичних втручань у пацієнтів 3 ожирінням та наскільки він сильний. Дані проспективного когортного дослідження Liu B. зі співавт. свідчать про те, що зростання IMT було пов'язане з підвищеним ризиком протезування колінного суглоба (RR 10.51) або протезування кульшового суглоба (RR 2,47) при порівнянні групи з високим IMT з групою з низьким IMT [14]. Автори встановили, що $69 \%$ протезування колінного суглоба і 27 \% протезування кульшового суглоба обумовлені надмірною масою тіла і ожирінням [14].

В іншому масштабному популяційному проспективному когортному дослідженні Lohmander зі співавт. [15] також виявили, що IMT суттєво асоціюється 3 частотою артропластики коліна (RR 8.1) і кульшового суглоба (RR 2,6) з безперервною залежністю збільшення - реакція між IMT та ризиком артропластики. Автори скоригували можливу упередженість вибору здорових пацієнтів для операції, виключивши з аналізу пацієнтів з іншими супутніми захворюваннями [15]. Таким чином, можна зробити висновок, що IMT пов'язаний з прогресуванням ОА колінного суглоба, тоді як доказова база щодо впливу надмірної маси тіла на розвиток ОА кульшового суглоба залишається недостатньою.

МРТ-ознаки остеоартрозу у осіб з надлишковою масою тіла. МРТ-дослідження за останні роки стало найбільш чутливим методом для виявлення дегенеративних змін суглобів та визначення їх наслідків на ранніх стадіях.

Laberge та співавт. [17] досліджували за допомогою МРТ колінний суглоб 137 осіб середнього віку на початковому етапі захворювання ОА та через 3 роки. Вони виявили, що ожиріння було пов'язане з більш високою поширеністю i тяжкістю ранніх дегенеративних змін у коліні в осіб середнього віку без рентгенологічних ознак колінного ОА і зі значно підвищеною прогресією ураження хряща. На початку дослідження поширеність і тяжкість уражень колінного суглоба були прямо пропорційно пов'язані з IMT, з майже чотириразовим збільшенням розривів меніска і 3 більш ніж дворазовим збільшенням виражених дефектів хряща в осіб з ожирінням щодо осіб 3 нормальною масою тіла. За 3-річний період спостереження кількість нових випадків уражень хряща або погіршення перебігу патологічного процесу у хрящі була значно вищою у пацієнтів 3 ожирінням $(p=0,039)$, тоді як в прогресуванні уражень меніска суттєвої різниці виявлено не було. Таким чином, за результатами дослідження ожиріння не призводило до підвищення ризику уражень менісків або кісткової структури протягом 36 міс.

У перехресному дослідженні 77 пацієнтів, що страждають на ожиріння (30 \% з яких мали клінічні ознаки ОА колінного суглоба), зміни в структурі хряща не були пов'язані з IMT, що оцінювалось за допомогою МРТ з використанням контрасту (dGEMRIC) [19].

Дослідницька група Pelletier J. зі співавт. [23], яка протягом двох років оцінювала регіональні зміни в колінному суглобі при ОА за допомогою МРТ, виявила, що ІМТ був одним із найсильніших предикторів втрати хряща $з$ центральної області медіального плато великогомілкової кістки та медіального виростка стегна.

Патофрізіологія остеоартрозу у осіб з ожирінням. Патофрізіологія пов'язаного з ожирінням остеоартрозу досить багатофакторна. Вважається, що структурні пошкодження суглоба $\epsilon$ наслідком дії як механічних фракторів (збільшення дії маси тіла на суглоб, зниження м'язової сили і зміни біомеханіки під час повсякденної діяльності) [24, 25], так і метаболічних фракторів [2].

Процеси метаболічних змін, внаслідок яких ожиріння сприяє структурному пошкодженню суглоба, на сьогодні невідомі, хоча вважається, що вони включають порушення синтезу адипокіну з подальшим ефектом, що призводить до руйнування і ремоделювання суглобової тканини [26, 27]. Адипокіни впливають на тканини суглобів, у тому числі на хрящ, синовіальну оболонку і кістки. Лептин і адипонектин $€$ найбільш відомими адипокінами [29], їхні рецептори синтезуються на поверхні хондроцитів, синовіоцитів субхрондральних остеобластів [30-32]. Виявлено, що лептин підвищує рівень деградуючих фрерментів, таких, як матриксні металопротеїнази (МMP) і оксид азоту, і продукує прозапальні цитокіни [30, 33-35]. Рівень адипокіну у людей з ожирінням може відігравати визначальну роль, оскільки ожиріння може створювати біохімічне середовище, в якому хондроцити втрачають свої функціональні властивості. Наприклад, було показано, що хондроцити пацієнтів з ожирінням при ОА проявляють характерні реакції на лептин, відмінні від пацієнтів з нормальною або надлишковою масою тіла [36]. 
Таким чином, деякі автори припускають, що OA $€$ не просто хворобою старіння суглобів, а метаболічним порушенням, при якому різні взаємопов'язані ліпідні, метаболічні та гуморальні медіатори сприяють ініціації і прогресуванню процесу захворювання [39].

У великому когортному дослідженні показано, що накопичення компонентів метаболічного синдрому було пов'язане з частотою і прогресуванням компонентів ОА колінного суглоба [41]. Вчені Chingford study виявили зв'язок між метаболічними факторами (гіпертонією, гіперхолестеринемією і рівнем глюкози крові) і ОА колінного суглоба у жінок, який не залежав від ожиріння, що також підтверджує думку про те, що ОА має важливі системні і метаболічні компоненти в своїй етіології, а не лише механічний фрактор дії надлишкової маси тіла [41].

Таким чином, аналізуючи дані авторів можна зробити висновок, що прогресування ОА пов'язано зі збільшенням IMT, хоча доказова база потребує більш детального вивчення.

\section{Кореляція між антропометричними даними і компонентним складом тіла та ризиком розВитку остеоартрозу}

Незважаючи на те що IMT $є$ об'єктивним показником для оцінки і демонстрації залежності ризику ОА від маси тіла, також ведеться дискусія про те, який ступінь ожиріння найбільше корелює з ризиком OA. Lohmander і співавт. [15] виявили, що показник IMT мав максимальний зв'язок 3 тяжким ОА (який потребував артропластики) порівняно з іншими показниками ожиріння, такими, як співвідношення талія/сте́гна і відсотковий вміст жиру в організмі (виміряний біоелектричним імпедансом).

У дослідженні «випадок-контроль», проведеному Holliday і співавт. [11], оцінювались ризики, пов'язані з високим IMT та іншими антропометричними показниками ожиріння. Автори використовували діаграму для пацієнтів, щоб ті могли самостійно оцінити фрорму свого тіла. ІМТ був пов'язаний з ОА колінного суглоба (OR: 2,68; 95 \% Cl: 2,33-3,09, p < 0,001) і ОА кульшового суглоба (OR: 1,65; 95 \% Cl: $1,46-1,87, \mathrm{p}<0,001)$. Оцінка форми тіла була також пов'язана з ОА колінного суглоба і ОА кульшового суглоба, за аналогією з показниками IMT. Співвідношення талія/сте́гна (WHR) на вихідному рівні не асоціювалося з ОА незалежно від IMT, за винятком тільки декількох випадків. Окружність талії була пов'язана з ризиком ОА нижніх кінцівок.

\section{Зменшення маси тіла та прояву остеоартрозу}

У ряді досліджень було продемонстровано, що втрата маси тіла дозволяє зменшити як больові відчуття пацієнтів, так і покращити функцію суглоба у пацієнтів з ожирінням та ОА колінного суглоба [47]. За результатами досліджень Gudbergsen і співавт. [48] виявлено, що зниження маси тіла забезпечує симптоматичне полегшення в осіб з ожирінням та ОА колінного суглоба незалежно від тяжкості його ушкодження. Авторами проведено дослідження 175 пацієнтів з IMT $>30$ кг $\times \mathrm{M}^{-2}$ i клінічними ознаками OA колінного суглоба, який визначався за допомогою МРТ на початку дослідження і через 16 тиж. після застосування низько енергетичної дієти. У цьому дослідженні у більшості пацієнтів спостерігалось значне зменшення маси тіла (> $10 \%$ ), а у $64 \%$ пацієнтів спостерігалося значне фрункціональне покращення стану суглоба за шкалою вимірювання фрізичної фрункції OMERACT-OARSI. Зменшення болю $(r=-0,05 ; p=0,49)$ було пов'язано зі втратою маси тіла, але не зі структурними змінами колінного суглоба за даними МРТ. Подібні результати були визначені і для фрізичної функції. Це свідчить про те, що виражена дегенерація колінного суглоба не перешкоджає досягти позитивних клінічних змін з боку суглобів, якщо пацієнт втрачає масу тіла, тому слід заохочувати пацієнтів з ожирінням до схуднення на будь-якій стадії ОА.

Дослідження, проведене Richette i співавт. [39], показало, що зменшення маси тіла за допомогою хірургічного втручання (у середньому на $20 \%$ ) привело до значного зниження рівня болю і покращення фуннкцій суглобів у пацієнтів через 6 міс. Обстежені пацієнти мали в середньому IMT $51 \mathrm{kг} \times$ м $^{-2}$ на вихідному рівні. За результатами досліджень за всіма підрозділами шкали WOMAC: біль (-50\%; $<<0,001)$, тугорухливість зменшилась $(-47 \% ; p<0,001)$, функції суглоба покращились $(-57 \% ; p<0,001)$. Також у пацієнтів виявлено зниження маркера деградації хряща (СОМР), але для оцінки структурних змін автори не використовували результати рентгенографії або MPT. Також Christensen та співавт. [48] в мета-аналізі чотирьох інтервенційних досліджень за участю 454 пацієнтів з надмірною масою тіла з ОА колінного суглоба виявили, що зменшення маси тіла привело до значного зниження фрізичної інвалідності.

Пацієнти з ожирінням та ОА, які втрачають масу тіла, можуть спостерігати поліпшення симптомів ОА з кількох причин. Когортне досліджен- 
ня Messier та співавт. [51] показало співвідношення втрати маси тіла $1: 4$ до зменшення навантаження на колінний суглоб, що вказує на те, що втрата 1 кг маси тіла призведе до зниження механічного навантаження на колінний суглоб на 4 кг під час ходьби.

Forsythe і співавт. [52] в мета-аналізі 66 заходів зі зниження маси тіла виявив, що схуднення було пов'язане зі зменшенням рівня таких запальних чинників, як С-реактивний білок (CRP), фрактор некрозу пухлини (TNF) і інтерлейкін-6 (IL-6), які були пов'язані з порушенням фрізичної функції.

\section{Висновки}

1. Патофрізіологія пов'язаного з ожирінням OА досить багатофракторна. Вважається, що структурні пошкодження суглоба $€$ наслідком дії як механічних факторів (збільшення дії ваги на

\section{References}

1. World Health Organization: Obesity and overweight. Fact Sheet №311. accessed on November 20, 2012. 2013. Mar, Available from: http: // www.who.int/mediacentre/factsheets/fs311/en/

2. Fransen M, March L. Obesity and the musculoskeletal system. Curr. Opin. Rheumatol. 2009;21:71-7.

3. Brooks PM. Impact of osteoarthritis on individuals and society: how much disability? Social consequences and health economic implications. Curr. Opin. Rheumatol. 2002;14:573-7.

4. Caterson I, Sambrook P, Fransen M, March L. The impact of obesity on the musculoskeletal system. Int. J. Obes. (Lond). 2008;32:211-22.

5. Spector TD, Hart DJ, Doyle DV. Incidence and progression of osteoarthritis in women with unilateral knee disease in the general population: the effect of obesity. Ann. Rheum. Diseases. 1994;53:565-8.

6. Szoeke C, Dennerstein L, Guthrie J, Clark M, Cicuttini F. The relationship between prospectively assessed body weight and physical activity and prevalence of radiological knee osteoarthritis in postmenopausal women. J. Rheumatol. 2006;33:1835-40.

7. Coggon D, Reading I, Croft P, McLaren M, Barrett D, Cooper C. Knee osteoarthritis and obesity. Int. J. Obes. Relat. Metab. Disord. 2001; 25:622-7.

8. Blagojevic M, Jinks C, Jeffery A, Jordan KP. Risk factors for onset of osteoarthritis of the knee in older adults: a systematic review and metaanalysis. Osteoarthritis Cartilage. 2010;18:24-33.

9. Jiang L, Rong J, Wang Y, Hu F, Bao C, Li X, et al. The relationship between body mass index and hip osteoarthritis: a systematic review and meta-analysis. Joint Bone Spine. 2011;78:150-5.

10. Jiang L, Tian W, Wang Y, Rong J, Bao C, Liu Y, et al. Body mass index and susceptibility to knee osteoarthritis: a systematic review and metaanalysis. Joint Bone Spine. 2012;79:291-7.

11. Holliday KL, McWilliams DF, Maciewicz RA, Muir KR. Lifetime body mass index, other anthropometric measures of obesity and risk of knee or hip osteoarthritis in the GOAL case-control study. Osteoarthritis Cartilage. 2011;19:37-43.

12. Reijman M, Pols HA, Bergink AP, Hazes JM, Belo JN, Lievense $\mathrm{AM}$, et al. Body mass index associated with onset and progression of osteoarthritis of the knee but not of the hip: the Rotterdam Study. Ann. Rheum. Diseases. 2007;66:158-62.

13. Brandt KD, Mazzuca SA. Experience with a placebo-controlled randomized clinical trial of a disease-modifying drug for osteoarthritis: the doxycycline trial. (xi-xii). Rheum. Dis. Clin. North Am. 2006;32:217-34. суглоб, зниження м'язової сили і зміни біомеханіки під час повсякденної діяльності), так і метаболічних фракторів.

2. Аналіз представлених літературних джерел свідчить, що процеси метаболічних змін, внаслідок яких ожиріння сприяє структурному пошкодженню суглоба, в даний час невідомі. Однак вважається, що біохімічні зміни порушують синтез адипокіна з подальшим ефектом, що приводить до руйнування і ремоделювання суглобової тканини.

3. Втрата маси тіла важлива як для запобігання, так і для лікування ОА колінного суглоба. У ряді досліджень встановлено, що втрата маси тіла дозволяє зменшити як больові відчуття пацієнтів, так і покращити фуннцію суглоба у пацієнтів з ожирінням та гонартрозом.

14. Liu B, Balkwill A, Banks E, Cooper C, Green J, Beral V. Relationship of height, weight and body mass index to the risk of hip and knee replacements in middle-aged women. Rheumatology (Oxford). 2007;46:861-7.

15. Lohmander LS, de Verdier Gerhardsson M, Rollof J, Nilsson PM. Incidence of severe knee and hip osteoarthritis in relation to different measures of body mass: a population-based prospective cohort study. Ann. Rheum. Diseases. 2009;68:490-6.

16. Franklin J, Ingvarsson T, Englund M, Lohmander LS. Sex differences in the association between body mass index and total hip or knee joint replacement resulting from osteoarthritis. Ann. Rheum. Diseases. 2009;68:536-40.

17. Laberge MA, Baum T, Virayavanich W, Nardo L, Nevitt MC, Lynch $J$, et al. Obesity increases the prevalence and severity of focal knee abnormalities diagnosed using $3 T$ MRI in middle-aged subjects - data from the Osteoarthritis Initiative. Skeletal Radiol. 2012;41:633-41.

18. Wang Y, Wluka AE, English DR, Teichtahl AJ, Giles GG, O'sullivan $\mathrm{R}$, et al. Body composition and knee cartilage properties in healthy, community-based adults. Ann. Rheum. Diseases. 2007;66:1244-8.

19. Anandacoomarasamy A, Giuffe BM, Leibman S, Caterson ID, Smith GS, Fransen M, et al. Delayed gadolinium-enhanced magnetic resonance imaging of cartilage: clinical associations in obese adults. J. Rheumatol. 2009;36:1056-62.

20. Hanna FS, Bell RJ, Davis SR, Wluka AE, Teichtahl AJ, O'sullivan $\mathrm{R}$, et al. Factors affecting patella cartilage and bone in middle-aged women. Arthritis Rheum. 2007:57:272-8.

21. Teichtahl AJ, Wluka AE, Wang Y, Hanna F, English DR, Giles GG, et al. Obesity and adiposity are associated with the rate of patella cartilage volume loss over 2 years in adults without knee osteoarthritis. Ann. Rheum. Diseases. 2009;68:909-13.

22. Teichtahl AJ, Wang Y, Wluka AE, Szramka M, English DR, Giles GG, et al. The longitudinal relationship between body composition and patella cartilage in healthy adults. Obesity (Silver Spring) 2008;16:421-7.

23. Pelletier JP, Raynauld JP, Berthiaume MJ, Abram F, Choquette D, Haraoui $B$, et al. Risk factors associated with the loss of cartilage volume on weight-bearing areas in knee osteoarthritis patients assessed by quantitative magnetic resonance imaging: a longitudinal study. Arthritis Res. Ther. 2007:9:74.

24. Runhaar J, Koes BW, Clockaerts S, Bierma-Zeinstra SM. A systematic review on changed biomechanics of lower extremities in obese individuals: a possible role in development of osteoarthritis. Obes. Rev. 2011;12:1071-82. 
25. King LK, Birmingham TB, Kean CO, Jones IC, Bryant DM, Giffin JR. Resistance training for medial compartment knee osteoarthritis and malalignment. Med. Sci. Sports Exerc. 2008;40:1376-84.

26. Oliveria SA, Felson DT, Cirillo PA, Reed JI, Walker AM. Body weight, body mass index, and incident symptomatic osteoarthritis of the hand, hip, and knee. Epidemiology. 1999;10:161-6.

27. Ouchi N, Parker JL, Lugus JJ, Walsh K. Adipokines in inflammation and metabolic disease. Nat. Rev. Immunol. 2011;11:85-97.

28. Gomez R, Conde J, Scotece M, Gomez-Reino JJ, Lago F, Gualillo $O$. What's new in our understanding of the role of adipokines in rheumatic diseases? Nat. Rev. Rheumatol. 2011;7:528-36.

29. Garnero P, Rousseau JC, Delmas PD. Molecular basis and clinical use of biochemical markers of bone, cartilage, and synovium in joint diseases. Arthritis Rheum. 2000;43: 953-68.

30. Tilg H, Moschen AR. Adipocytokines: mediators linking adipose tissue, inflammation and immunity. Nat. Rev. Immunol. 2006;6:772-83.

31. Simopoulou T, Malizos KN, lliopoulos D, Stefanou N, Papatheodorou L, loannou M, et al. Differential expression of leptin and leptin's receptor isoform $(\mathrm{Ob}-\mathrm{Rb}) \mathrm{mRNA}$ between advanced and minimally affected osteoarthritic cartilage; effect on cartilage metabolism. Osteoarthritis Cartilage. 2007:15:872-83.

32. Figenschau Y, Knutsen G, Shahazeydi S, Johansen O, Sveinbjornsson B. Human articular chondrocytes express functional leptin receptors. Biochem. Biophys. Res. Commun. 2001;287:190-7.

33. Karsenty G. Convergence between bone and energy homeostases: leptin regulation of bone mass. Cell. Metab. 2006;4:341-8.

34. Otero M, Gomez Reino JJ, Gualillo O. Synergistic induction of nitric oxide synthase type II: in vitroeffect of leptin and interferon-gamma in human chondrocytes and ATDC5 chondrogenic cells. Arthritis Rheum. 2003:48:404-9.

35. Lago F, Reino JJ, Gualillo O. Signalling pathway involved in nitric oxide synthase type II activation in chondrocytes: synergistic effect of leptin with interleukin-1. Arthritis Res. Ther. 2005;7:581-91.

36. Vuolteenaho K, Koskinen A, Kukkonen M, Nieminen R, Paivarinta $U$, Moilanen T, et al. Leptin enhances synthesis of proinflammatory mediators in human osteoarthritic cartilage-mediator role of $\mathrm{NO}$ in leptin-induced PGE2, IL-6, and IL-8 production. Mediators Inflamm. 2009. 2009:345838.

37. Pallu S, Francin PJ, Guillaume C, Gegout-Pottie P, Netter P, Mainard $D$, et al. Obesity affects the chondrocyte responsiveness to leptin in patients with osteoarthritis. Arthritis Res. Ther. 2010;12:112.

38. Boer TN, van Spil WE, Huisman AM, Polak AA, Bijlsma JW, Lafeber FP, et al. Serum adipokines in osteoarthritis; comparison with controls and relationship with local parameters of synovial inflammation and cartilage damage. Osteoarthritis Cartilage. 2012;20:846-53.

39. Richette P, Poitou C, Garnero P, Vicaut E, Bouillot JL, Lacorte JM, et al. Benefits of massive weight loss on symptoms, systemic inflamma- tion and cartilage turnover in obese patients with knee osteoarthritis. Ann. Rheum. Diseases. 2011;70:139-44.

40. Velasquez MT, Katz JD. Osteoarthritis: another component of metabolic syndrome? Metab. Syndr. Relat. Disord. 2010;8:295-305.

41. Yoshimura N, Muraki S, Oka H, Tanaka S, Kawaguchi H, Nakamura $\mathrm{K}$, et al. Accumulation of metabolic risk factors such as overweight, hypertension, dyslipidaemia, and impaired glucose tolerance raises the risk of occurrence and progression of knee osteoarthritis: a 3-year follow-up of the ROAD study. Osteoarthritis Cartilage. 2012;20:1217-26.

42. Hart DJ, Doyle DV, Spector TD. Association between metabolic factors and knee osteoarthritis in women: the Chingford Study. J. Rheumatol. 1995;22:1118-23.

43. Triantaphyllidou IE, Kalyvioti E, Karavia E, Lilis I, Kypreos KE. Perturbations in the HDL metabolic pathway predispose to the development of osteoarthritis in mice following long-term exposure to western-type diet. Osteoarthritis Cartilage. 2013;21:322-30.

44. Karvonen-Gutierrez CA, Sowers MR, Heeringa SG. Sex dimorphism in the association of cardiometabolic characteristics and osteophytesdefined radiographic knee osteoarthritis among obese and non-obese adults: NHANES III. Osteoarthritis Cartilage. 2012;20:614-21.

45. Berry PA, Wluka AE, Davies-Tuck ML, Wang Y, Strauss BJ, Dixon JB, et al. The relationship between body composition and structural changes at the knee. Rheumatology (Oxford) 2010;49:2362-9.

46. Brouwer GM, van Tol AW, Bergink AP, Belo JN. Association between valgus and varus alignment and the development and progression of radiographic osteoarthritis of the knee. Arthritis Rheum. 2007;56:1204-11.

47. Sowers MF, Yosef M, Jamadar D, Jacobson J. BMl vs. body composition and radiographically defined osteoarthritis of the knee in women: a 4-year follow-up study. Osteoarthritis Cartilage. 2008;16:367-72.

48. Christensen R, Bartels EM, Astrup A, Bliddal H. Effect of weight reduction in obese patients diagnosed with knee osteoarthritis: a systematic review and meta-analysis. Ann. Rheum. Diseases. 2007;66:433-9.

49. Gudbergsen H, Boesen M, Lohmander LS, Christensen R. Weight loss is effective for symptomatic relief in obese subjects with knee osteoarthritis independently of joint damage severity assessed by high-field MRI and radiography. Osteoarthritis Cartilage. 2012;20:495-502.

50. Bliddal H, Leeds AR, Stigsgaard L, Astrup A, Christensen R. Weight loss as treatment for knee osteoarthritis symptoms in obese patients: 1 -year results from a randomised controlled trial. Ann. Rheum. Diseases. 2011;70:1798-803.

51. Messier SP, Gutekunst DJ, Davis C, DeVita P. Weight loss reduces knee-joint loads in overweight and obese older adults with knee osteoarthritis. Arthritis Rheum. 2005;52:2026-32.

52. Forsythe LK, Wallace JM, Livingstone MB. Obesity and inflammation: the effects of weight loss. Nutr. Res. Rev. 2008;21:117-33. 